\title{
Honoré De Balzac, Illusioni perdute
}

\section{Marco Stupazzoni}

\section{(2) OpenEdition}

\section{Journals}

\section{Edizione digitale}

URL: http://journals.openedition.org/studifrancesi/8301

DOI: 10.4000/studifrancesi.8301

ISSN: 2421-5856

\section{Editore}

Rosenberg \& Sellier

\section{Edizione cartacea}

Data di pubblicazione: 1 mai 2009

Paginazione: 192

ISSN: 0039-2944

\section{Notizia bibliografica digitale}

Marco Stupazzoni, «Honoré De Balzac, Illusioni perdute», Studi Francesi [Online], 157 (LIII | I) | 2009,

online dal 30 novembre 2015, consultato il 07 avril 2021. URL: http://journals.openedition.org/ studifrancesi/8301 ; DOI: https://doi.org/10.4000/studifrancesi.8301

\section{Questo documento è stato generato automaticamente il 7 avril 2021.}

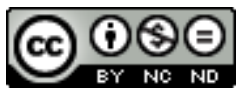

Studi Francesi è distribuita con Licenza Creative Commons Attribuzione - Non commerciale - Non opere derivate 4.0 Internazionale. 


\title{
Honoré De Balzac, Illusioni perdute
}

\author{
Marco Stupazzoni
}

NOTIZIA

HONORÉ DE BALZAC, Illusioni perdute, introduzione di Lanfranco BINNI, traduzione di Argia MICCHETTONI, Milano, Garzanti, «I grandi libri», 2007, pp. LXIII-653.

1 Giunta ormai alla sua undicesima edizione, è riproposta al pubblico italiano la traduzione di Illusions perdues dovuta ad A. Micchettoni e risalente al 1966. 